Communication, creativity, innovations

Komunikacija, kūrybiškumas, inovacijos

\title{
CREATIVITY AND SPECIALITY LANGUAGE IN THE CONTEXT OF THE DEVELOPMENT OF KEY COMPETENCES
}

\author{
Angelika PETRÉTIENĖ (iD ${ }^{1^{*}}$, Jacinta DAUKŠIENÉ2 ${ }^{2}$ Jolita GRAŠIENĖ (iD) ${ }^{3}$ \\ 1, 2 Vilnius Gediminas Technical University, Vilnius, Lithuania \\ ${ }^{3}$ Vilnius College of Technologies and Design, Vilnius, Lithuania
}

Received 02 January 2020; accepted 21 January 2020

\begin{abstract}
The article gives an overview of the classification of key competences, discusses their importance for the development of every aspect of personality capable of competing in the labour market and able to adapt to the changing working conditions and situations. The article presents a survey carried out at Vilnius Gediminas Technical University and Vilnius College of Technologies and Design, the purpose of which was to find out the importance of key competences to Vilnius Gediminas Technical University and Vilnius College of Technologies and Design students, as well as to examine which key competences can be best developed during speciality language lectures. It provides examples of practical tasks and recommendations that help to achieve better results of key competences development when teaching speciality language.
\end{abstract}

Nowadays a lot of attention is devoted to creativity. It is often defined as one the most important key competences. The article discusses the concept of creativity and aspects of its development during speciality language lectures.

Keywords: creativity, key competences, quality of studies, questionnaire survey, speciality language, students.

\section{Introduction}

Why have key competences become so relevant in recent decades and are described as the competences of the 21 st century? (Jakubè \& Juozaitis, 2012).

According to Laužackas (2005), successful participation of tertiary education graduates in the labour market depends not only on special skills or competences, but also on key skills or competences, therefore key competences are becoming as important as subject knowledge and skills. As the labour market relies more and more on higher qualification and key competences, higher education must ensure that students acquire knowledge, skills and competences that they will need in their professional activities (kokybe.viko.lt, 2017), i.e. competences to work in a new environment, to promote continuous improvement, the ability to communicate and cooperate with professionals in different areas, to solve problems when organizing activities and to foster other key competences, to create a culture of continuous (and not one-time) learning, which encourages students and graduates to attempt and be able to continue learning in a changing and information-loaded environment (Glosiene, 2006). According to Grincevičienè (2010), when faced with educational reality, the educational process development model constructed by strategists acquired a new quality.

Nowadays a lot of attention is devoted to the development of creativity, and its concept has become much wider. Creativity is now understood not only as an individual process, but also as a well-defined and well-structured collective process. Creativity can manifest itself not only in the artistic field, but also in all other areas of activity (Černevičiūtè \& Strazdas, 2014). Dapkus (2006) defines creativity as the ability of people or groups of people to create something new by using the power of imagination. It is the ability to create and think independently, quickly orient oneself in a problematic situation and easily find non-standard and non-stereotypical solutions. Kačerauskas (2014) underlines that creativity is a distinctive feature of current times which makes our society different from any other communities of the past.

The objective of speciality language teaching is not only to teach correct speciality-related terms, to develop public speaking skills and to promote responsibility for one's native tongue, its preservation and fostering, but also to develop key competences of students.

${ }^{*}$ Corresponding author. E-mail: angelika.petretiene@vgtu.lt 
The aim of the article is to ascertain the importance of key competences for students of Vilnius Gediminas Technical University (VGTU) and Vilnius College of Technologies and Design (VCTD), to examine to which key competences speciality language lectures contribute the most and to discuss factors stimulating creativity when teaching this subject.

\section{Objectives:}

1. To explain the concept of key competences and provide an overview of their classification.

2. To show the attitude of VGTU and VCTD students towards development of key competences during speciality language lectures.

3. To show the opinion of VGTU and VCTD students on the impact of correct language usage to professional success.

4. To provide examples of practical tasks and recommendations that can benefit the development of creativity and help achieve better results in the area of the development of key competences during speciality language lectures.

5. To determine the importance of creativity among the key competences based on the results of the survey.

Survey methods: literature review, questionnaire survey, data systematisation and summarisation.

\section{Concept and classification of key competences}

Various sources (Subotkevičienè, 2004; Europos Komisija, 2012; European Commission, 2017) use different terms to define key competences: key skills, basic and transversal skills, core skills, key competences, etc. In this article the term key competences was chosen, as it is most commonly used and covers the highest number of competences.

The concept of key competences has been defined by many scholars in Lithuania. For example, Laužackas (2005) defines key competences as core competences and general abilities that are drivers of overall personality development, professional flexibility and mobility. According to Martišauskienè (2010), they are an external expression of essential human powers combining both inherent talents and acquired knowledge, experience and developed disposition to implement them. In other words, they are the quintessence of all human powers concentrated on specific situations.

The following paragraphs describe classifications of key competences in various sources.

Kirby and Žydžiūnaitė (1999) classify key competences as follows:

1. Communication.

2. Information technologies.

3. Foreign languages.

4. Personal development.

5. Problem resolution.

6. Team work.

The "Recommendation of the European Parliament and of the Council of 18 December 2006 on Key Com- petences on Lifelong Learning" (EUR-Lex: Access to European Union Law, 2006) defines the following key competences:

1. Communication in the mother tongue.

2. Communication in foreign languages.

3. Mathematical competence and basic competences in science and technology.

4. Digital competence.

5. Learning to learn.

6. Social and civic competences.

7. Sense of initiative and entrepreneurship competence.

8. Cultural awareness and expression.

Methodical recommendations by Jakubė and Juozaitis (2012) describe in detail which key competences are important for the Lithuanian higher education institutions. The authors based their opinion on the national project that was carried out in Lithuania in 2009-2012 "Development of the Concept of the European Credit Transfer and Accumulation System (ECTS) at the National Level: Harmonization of Credits and Implementation of the Learning Outcomes Based Study Programme Design". When they developed and implemented the national concept of the European Credit Transfer and Accumulation, the project experts followed the methodology of the project "Tuning Educational Structures in Europe". The publication (Jakube \& Juozaitis, 2012) defines creativity as the ability to generate new ideas.

The importance of the mother tongue is highlighted in the National Progress Strategy (Lietuvos Respublikos Seimas, 2012): it is proposed to consolidate the Lithuanian studies as the basis for humanistic education, encompassing training of generic cultural competences, development of a creative individual, and public education. It seeks to ensure the fundamentals of humanities education in all the Lithuanian higher education schools. Therefore, speciality language teachers play an important role in contributing to the development of a versatile personality. The Yerevan Communiqué (The Eurasian Humanities Institute, 2017) underlines that it is essential to recognize and support quality teaching, and to provide opportunities for enhancing the academics' teaching competences. Both VGTU and VCTD organize training courses for teachers in order to familiarize them with objectives and possibilities of key competences development, as well as modern teaching methods that help to achieve those objectives in a faster and more efficient way.

On the basis of classifications derived from the above sources, the aim of this study was to find out students' opinions about developing the following key competences:

1. Learning to learn competence.

2. Communication competence.

3. Personal development competence.

4. Social and civic competence.

5. Creativity competence.

6. Cultural awareness and expression competence.

7. Communication in the mother tongue competence. 


\section{Study on students' attitude towards the development of key competences during speciality language lectures}

A questionnaire survey was conducted in November 2016. There were 180 respondents: 90 4th year full-time students from the VGTU Faculty of Mechanics, from the study programs of Biomechanics, Production Engineering and Management, Innovative Production, Mechatronics and Robotics, Mechanical Engineering and Printing Engineering; and 90 full-time students from the VCTD Technical Faculty, from the study programs of Technical Maintenance of Automobiles (1st year students) and Automotive Electronics (2nd year students).

Figure 1 shows answers to the question "To which key competences speciality language lectures contribute the most?"

Both VGTU (42\%) and VCTD (37\%) students admit that communication competence is best developed during speciality language lectures. Such results correspond to the objectives of "Speciality Language Program" approved by the Commission of the Lithuanian Language on 12 June, 2014: the program is designed to improve the spoken and written speciality language in higher education institutions. Kirby and Žydžiūnaitė (1999) define communication competence as the ability to participate in a discussion, to speak, to write papers and use visual material, to read and express opinion about a written text. According to Fullan (2013), communication in a 21st century context refers not only to the ability to "communicate effectively, orally, in writing, and with a variety of digital tools" but also to "listening skills". In order to develop this competence, contemporary teaching methods should be applied more actively, i.e. inclusive lectures, presentations, team work, creativity, discussions, etc. (see Grašienè \& Petrètienè, 2017).

VGTU students (18\%) considered that the second most important competence is cultural awareness and expression, and VCTD students (23\%) thought it was personal development. The Bucharest Communiqué
(EHEA Ministerial Conference: Bucharest, 2012) emphasises that higher education should be an open process in which students develop intellectual independence and personal self-assuredness alongside disciplinary knowledge and skills. When studying and conducting surveys, students should acquire abilities to decisively evaluate situations and base their actions on critical thinking. The relevant literature (Kaffemanas, 2001; Ubartaité-Vingienè, 2007) devotes particular attention to the importance of (self-) development of critical thinking. According to Penkauskiene (2016, p. 95), most people can be both creative and think critically, because they have characteristics, dispositions and abilities that are common to both types of thinkers (curiosity and openness to new experience, ability to work consistently and with concentration, courage to take risks and responsibilities, tolerance of uncertainty, openness to various opinions or attitudes, ability to analyse and reflect, etc.). According to Paul and Elder (2007), critical thinking helps to notice creativity, novelties, originality and needs creative ideas (see Penkauskienè, 2016). During speciality language lectures, students should be encouraged to take a more active interest in the subject material, for example, by engaging them in scientific activities (Petrètiene \& Makaravičius, 2012) and giving them a possibility to choose a speciality language related homework assignment (as a main or secondary assignment), thereby contributing to the development of creativity competence.

Jatkauskiené and Tolutienè (2012) draw attention to the fact that not only the acquisition of information and knowledge, but also their structuring and use is becoming an important learning objective. This is one of the steps towards improving the learning to learn competence. It is important that students make the most efficient use of possibilities provided by information and communication technologies for learning purposes. Nowadays there are many linguistic websites and online dictionaries (see Petrètiene, 2016, pp. 18-22). The use of media also helps to develop creative personality. According to Kačerauskas (2014,

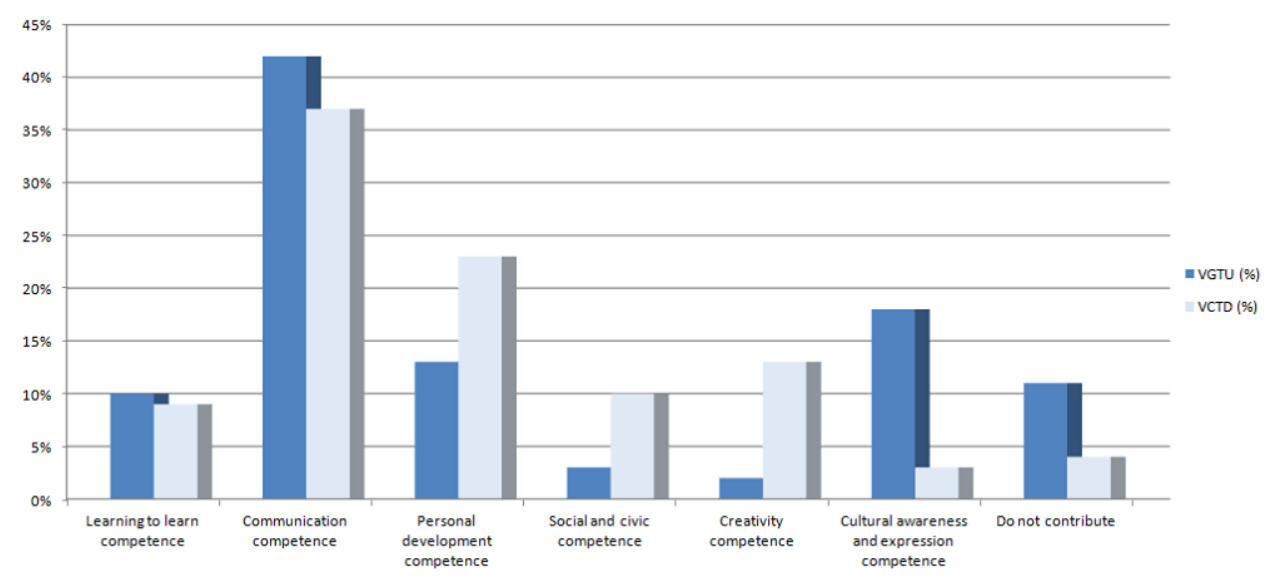

Figure 1. Replies to the question "To which key competences speciality language lectures contribute the most?" (source: created by authors) 
p. 40), media enables and initiates creativity by providing ideas for creative exchange. As regards new (digital) media, creation is understood as combination of elements provided by a database. This opens unlimited possibilities for creation, but at the same time constitutes a danger that one might succumb to the unifying taste of media and mass demand. Daujotyte (2009, p. 332) draws attention to the fact that today the variety of media is huge and still growing. More and more space is occupied by images and visual language. Without doubt, less information is transmitted by means of language. The author defines language as the oldest and the most important form of media, as the main provider of interpersonal communication. In the educational process, a fundamental role is played by the lecturer, a representative of a profession in which language is the main working tool. A good lecturer could well be described using the same set of qualities as a good orator: able to work creatively and think originally; hard working, continuously updating his or her knowledge; having inherent ability to influence, sensitive to others, receptive, observant; having good memory, able to improvise and speak without notes; energetic, communicative, social; ethical in all respects, etc. (Koženiauskienè, 2001, pp. 40-41). Creative lecturers who enjoy their work will undoubtedly be able to use modern media as a source of useful and easily accessible information and as a means of image transmission without overshadowing the main media - language.

Some speciality language tasks could require visiting libraries or museums (for example, the Museum of Energy and Technology and the Lithuanian Railway Museum (both in Vilnius) or other museums depending on the discipline studied). It would be useful to organize visits in order to hear from the authors themselves, for example, how important databases were created (Consultation and Term Banks, the Virtual Electronic Heritage System epaveldas. lt (Petrètienè, 2012)). Following an overview of various dictionaries, it could be possible to organize an excursion to the museum of Marija and Jurgis Šlapeliai (Marija and Jurgis Šlapeliai House-Museum). Among other things, the educational program is aimed at familiarising with Jurgis Šlapelis' Dictionary of Alien and Incomprehensible Words (in Lithuanian: Svetimu ir nesuprantamuz žodžiu žodynèlis, 1907); visitors can also participate in various games that aim at explaining the meaning of loanwords provided in this dictionary, and they can also look into the meanings and definitions of words in question in contemporary dictionaries and learn how meanings of words changed over more than a century. According to Kačerauskas (2014, p. 42), an environment that is conductive to the development of creative personality is an important driver of creativity. After their visit to the museum, students would find new ideas and are likely to become more critical about the question of substituting loanwords with their equivalents and to provide more constructive reasons for that substitution. Such visits would contribute to the development of cultural awareness and expression, creativity and personal competences.
The purpose of the second question in the questionnaire was to find out the students' opinion on whether key competences developed during their studies would be important in the future, i.e. in their professional activities. Respondents were asked to answer the following question: Do you think a specialist who has acquired key competences will find it easier to pursue a career and adapt to the labour market? The majority of both VGTU (79\%) and VCTD (80\%) students responded positively (Figure 2).

The ability to communicate orally and in writing in the mother tongue was excluded from the list of competences to be investigated (Figure 1). Developing this competence is the main purpose of speciality language lectures. The "Recommendation of the European Parliament and of the Council of 18 December 2006 on Key Competences on Lifelong Learning" (EUR-Lex: Access to European Union Law, 2006) defines communication in the mother tongue as the ability to express and interpret concepts, thoughts, feelings, facts and opinions in both oral and written form (listening, speaking, reading and writing), and to interact linguistically in an appropriate and creative way in a full range of societal and cultural contexts; in education and training, work, home and leisure. Langlotz (2015) draws attention, that "the creative potential of human minds is directly reflected in language structure and use. $\langle\ldots .$.$\rangle in a$ broad sense, the fundamental human capacity to create regular, but new, linguistic patterns, such as new words, sentences, or texts, can be regarded as reflecting language-based creativity. Secondly, linguistic creativity can also be associated with more unconventional communicative products that are creatively produced through language". It might be that the development of linguistic creativity to which speciality language lectures contribute determined positive replies to another question of the survey.

One of the objectives of the survey was to find out the students' opinion about the impact of correct language usage on professional success. Respondents were asked to answer the following question: Do you think that correct usage of the Lithuanian language can increase your employment opportunities and is important for concluding business transactions or convincing a client to use services

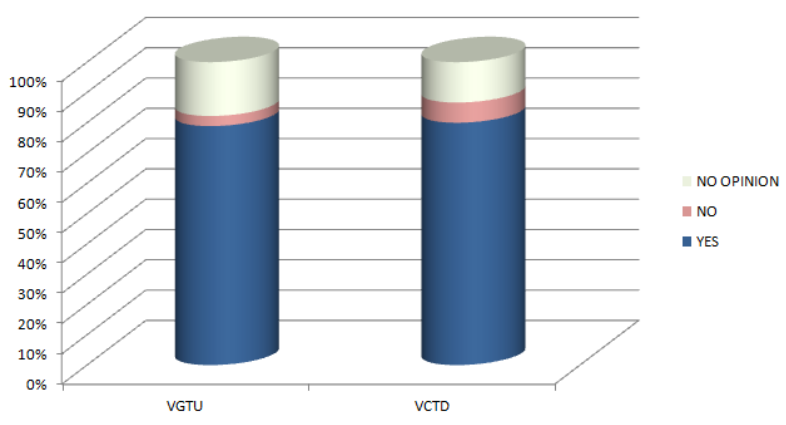

Figure 2. Students' opinion about the importance of key competences for pursuing a career and adapting to the labour market (source: created by authors) 
of your company? Although the majority of the VGTU $(82 \%)$ and VCTD (70\%) students replied positively (Figure 3), some of them chose to provide additional explanatory arguments, such as: "Yes, however, professional knowledge is very important", "Yes, however, professional competence and experience is of essential importance", "No, personal qualities are more important", "No, it is more important to be able to communicate". Subject-matter competence, respect for your client, courtesy, responsiveness, personal qualities, etc. are particularly important factors in the process of communicating with customers and business partners.

Statistical data provided in Figure 4 (replies to the question Which topics of speciality language discipline would you prioritize?) show that VGTU students (47\%) singled out public communication as the most important topic. As discussed earlier, VGTU and VCTD students are of the opinion that speciality language lectures provide the largest contribution to the development of communication competence. This need would be best addressed by public communication lectures. The smaller percentage of VCTD students who chose this topic could be explained by the possibility that some students think that they will "rather work with various types of equipment than communicate with people". Preparation and delivery of public speeches, forms of preparation and ways of delivery would be best explained by familiarizing students with the main theoretical aspects on the basis on which students would prepare a speech. Topics of such a speech prepared in accordance with the requirements for public speaking could be, for example, speciality language or public speaking. The lecturer could choose to write down a list of the mistakes observed or discuss them after the lecture or during consultations with each student individually.

VCTD students (46\%) gave priority to the topic of characteristics of scientific and professional language. According to Klimavičius (1980, p. 67), the motto of scientific and technical language is to name things precisely. It could be said that terminology is the basis of professional language, because professional language is speciality language supplemented in accordance with and adjusted to the needs of the relevant practical (professional) activity (Akelaitis et al., 2009, p. 20). Terminology knowledge

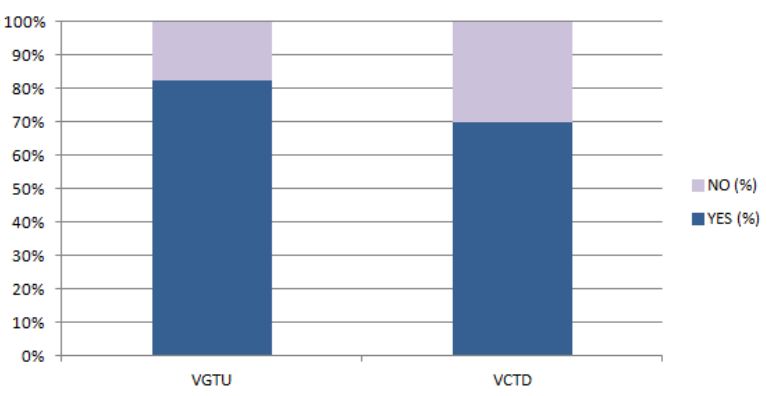

Figure 3. Students' opinion about the impact of correct usage of the Lithuanian language on professional success (source: created by authors)

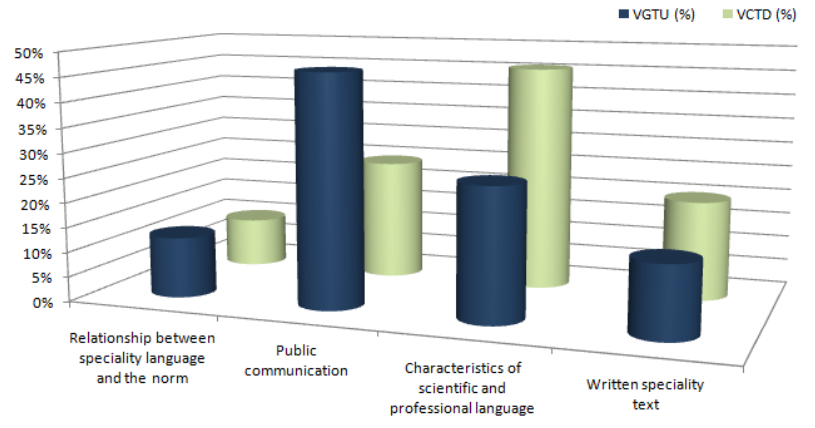

Figure 4. Relevance of speciality language program topics for future technical specialists (source: created by authors)

acquired during speciality language lectures is also likely to be useful for professional activities. Developed (or selfdeveloped) competences of learning to learn, creativity, personal development, etc., will stimulate further interest in this topic.

\section{Conclusions}

1. Developing key competences is necessary for the development of versatile personalities capable of competing in the labour market and adapting to constantly changing conditions.

2. The majority of VCTD students admit that speciality language lectures contribute best to the development of communication competence. Public communication lectures would probably contribute most to the development of this competence. This topic (public communication) was singled out as the most important by VGTU students. VCTD students gave priority to characteristics of scientific and professional language. When planning lectures and distributing hours, the students' opinion should be taken into account in order to enhance the practical relevance of subjects taught. VGTU students considered that the second most important competence is cultural awareness and expression, and VCTD students thought it was personal development. For the development of those competences, it is important to make the best possible use of opportunities provided by information and communication technologies. It would also be useful to visit libraries, museums, organize meetings with authors of dictionaries and developers of important electronic databases, etc.

3. The results of the survey to find out the students' opinion about the impact of correct language usage to professional success show that the majority of VGTU and VCTD students gave positive replies to this question; however, some respondents provided additional explanatory arguments emphasizing subject-matter competence, respect for your client, personal qualities, etc.

4. Contemporary teaching methods should be more actively used for the purpose of developing key competences. Those methods stimulate students' interest in 
the subject material, help to engage them in scientific activities, etc. From the broad range of methods available, the lecturer should choose those that are best suited to the level of preparedness and to the possibilities of a particular group of students.

5. Speciality language lectures should increase students' awareness of the concept of creativity, the understanding of which is much wider today. It is probable that students understand creativity in the narrow (traditional) sense of the word, i.e. as an individual process that materialises in an artistic dimension such as visual arts, performing arts or musical composition. Perhaps this could explain the relatively low percentage of students who chose the initiative and creativity competence.

\section{References}

Akelaitis, G., Pečkuviene, L. ir Žilinskienè, V. (2009). Specialybès kalba: administracines kalbos vadovèlis. Mykolo Romerio universiteto leidykla.

Černevičiūtė, J. ir Strazdas, R. (2014). Kūrybingumo sampratų raida: nuo genijaus ị kūrybines sistemas. Santalka: filosofija, komunikacija, 22(2), 113-125.

Dapkus, R. (2006). Inovaciju ekonomika: mokomoji knyga. Vitae Litera.

Daujotyte, V. (2009). Kalba ir jos menas. Lietuvių literatūros ir tautosakos instituto leidykla.

EHEA Ministerial Conference. Bucharest 2012. (2012). Making the most of our potential: Consolidating the European higher education area. Bucharest Communiqué. Final Version. http://www. enqa.eu/wp-content/uploads/2013/03/Bucharest-Communique-20121.pdf

EUR-Lex: Access to European Union Law. (2006). Recommendation of the European Parliament and of the Council of 18 December 2006 on key competences on lifelong learning. Official Journal of the European Union. https://eur-lex.europa. eu/legal-content/EN/ALL/?uri=celex:32006H0962

European Commission. (2017). Bendrieji gebejimai. http://ec.europa.eu/education/policy/school/competences_lt

Europos Komisija. (2012). Pagrindiniu kompetenciju ugdymas Europos mokyklose: politikos formavimo iššūkiai ir galimybes. https://op.europa.eu/en/publication-detail/-/publication/0fe17a38-e72e-44e7-8f68-231a5e9f0e18/language-lt

Fullan, M. (2013). Great to excellent: Launching the next stage of Ontario's education agenda. Ontario Ministry of Education. http://www.michaelfullan.ca/wp-content/uploads/2013/09/13_ Fullan_Great-to-Excellent.pdf

Glosienè, A. (2006). Akademinès bendruomenès informacinès kompetencijos ugdymas: po dvidešimties metų. Knygotyra, 47, 186-203.

Grašiené, J. ir Petrètienė, A. (2017). Klasikinių ir šiuolaikinių metodų taikymas dèstant specialybès kalbą. Pedagogika, 128(4), 193-205. https://doi.org/10.15823/p.2017.63

Grincevičienè, V. (2010). Mokyklos kaitos erdves ir linkmès: pedagoginis-sociologinis aspektas. Vilniaus pedagoginio universiteto leidykla.

Jakubè, A. ir Juozaitis, A. (2012). Bendruju kompetenciju ugdymas aukštojoje mokykloje: metodinés rekomendacijos. Vilniaus universiteto leidykla.

Jatkauskienė, B. ir Tolutienė, G. (2012). Aiškinamasis andragogikos terminu žodynas. Klaipėdos universiteto leidykla.
Kačerauskas, T. (2014). Kürybos visuomene. Vilniaus Gedimino technikos universiteto leidykla Technika. https://doi.org/10.3846/2265-M

Kaffemanas, R. (2001). Mąstymo psichologija. Šiaulių universiteto leidykla.

Kirby, J. ir Žydžiūnaitè, V. (1999). Bendrieji gebejjimai: mokytojo knyga. Phare.

Klimavičius, J. (1980). Vairuotojo vadovèlių terminai. Kalbos kultūra, 39, 67-76.

kokybe.viko.lt. (2017). Bolonijos procesas 2020 metais - Europos aukštojo mokslo erdvè naujajame dešimtmetyje. http://kokybe. viko.lt/uploads/Liuveno\%20komunikatas.pdf

Koženiauskienė, R. (2001). Retorika: iškalbos stilistika. Mokslo ir enciklopedijų leidybos institutas.

Langlotz, A. (2015). The Routledge handbook of language and creativity. https://www.routledgehandbooks.com/ doi/10.4324/9781315694566.ch2

Laužackas, R. (2005). Profesinio rengimo metodologija. Vytauto Didžiojo universiteto leidykla.

Lietuvos Respublikos Seimas. (2012). Lietuvos Respublikos Seimo nutarimas dèl Valstybès pažangos strategijos „Lietuvos pažangos strategija „Lietuva 2030“ patvirtinimo $2012 \mathrm{~m}$. gegužès 15 d. Nr. XI-2015. Valstybès žinios, 2012-05-30, Nr. 61-3050. https://e-seimas.lrs.lt/portal/legalAct/lt/TAD/TAIS.425517

Martišauskienè, E. (2010). Mokytojų požiūris ì gebėjimus kaip profesijos kompetencijos demeni. Acta Paedagogica Vilnensia, 24, 101-113. https://doi.org/10.15388/ActPaed.2010.24.3031

Paul, R., \& Elder, L. (2007). The Thinker's guide to the art of Socratic questioning. Based on critical thinking concepts \& tools. Foundation for Critical Thinking Press.

Penkauskienè, D. (2016). Kritinio ir kūrybinio mąstymo sąsaja. Socialine teorija, empirija, politika ir praktika, 13, 90-104. https://doi.org/10.15388/STEPP.2016.13.10045

Petrètienè, A. (2012, gruodžio 4 d.). Studentai lankèsi Nacionalinio skaitmeninimo ir virtualios elektroninio paveldo sistemos centre. Inžinerija, 10(1420), 4. http://www.vgtu.lt/media/ files/_1/inz-10-2012.pdf

Petrètienè, A. (2016). Transportininku kalbos kultūra: teorija ir praktika. Vilniaus Gedimino technikos universiteto leidykla Technika. https://doi.org/10.3846/1553-S

Petrètienè, A. ir Makaravičius, L. (2012). Leidinio „Autovežimis“ (1940 m.) terminijos analizè. Santalka: filologija, edukologija, 20(2), 180-193. https://doi.org/10.3846/cpc.2012.18

Subotkevičienè, R. (2004). Bendrieji gebejjimai - mokytojų kompetencijos ugdymo pagrindas. Tiltai, 3, 131-134.

Šlapelis, J. (Sud.). (1907). Svetimų ir nesuprantamu žodžiu žodynèlis. Šviesa.

The Eurasian Humanities Institute. (2017). Yerevan Communiqué. http://egi.kz/en/accreditation/yerevan-communique/

Ubartaite-Vingienė, D. (2007). Kritinio mastymo ugdymas formaliajame suaugusiuju švietime: teorija ir jos praktinis taikymas paskaitose. Versus Aureus.

\section{KŪRYBIŠKUMAS IR SPECIALYBĖS KALBA BENDRŲJŲ KOMPETENCIJU UGDYMO KONTEKSTE}

\section{A. Petrètienè, J. Daukšienè, J. Grašienė}

Santrauka

Straipsnyje apžvelgiama bendrųjų kompetencijų klasifikacija, aptariama jų svarba siekiant išugdyti ịvairiapusę asmenybę, gebančią konkuruoti darbo rinkoje, prisitaikančią prie nuolat kintančių darbo sąlygų ir situacijų. Pristatomas Vilniaus 
Gedimino technikos universitete ir Vilniaus technologijų ir dizaino kolegijoje atliktas tyrimas, kuriuo siekta išsiaiškinti bendrųjų kompetencijų svarbą šių aukštujų mokyklų studentams, ištirti, kurias bendrąsias kompetencijas labiausiai padeda ugdyti specialybės kalbos paskaitos. Pateikiama praktinių užduočių pavyzdžių, rekomendacijų, padedančių igyti geresnių bendrųjų kompetenijų ugdymo rezultatų per specialybès kalbos paskaitas.
Šiuo metu daug dèmesio skiriama kūrybiškumui. Jis neretai apibūdinamas kaip viena svarbiausių kompetencijų. Straipsnyje aptariama kūrybiškumo samprata, jo ugdymo per specialybès kalbos paskaitas aspektai.

Reikšminiai žodžiai: kūrybiškumas, bendrosios kompetencijos, studijų kokybė, anketinė apklausa, specialybès kalba, studentai. 